ISSN 0103-5150

Fisioter. Mov., Curitiba, v. 27, n. 4, p. 675-689, out./dez. 2014

Licenciado sob uma Licença Creative Commons

DOI: http://dx.doi.org.10.1590/0103-5150.027.004.AR02

\title{
The effect of pelvic floor muscle training in urinary incontinent elderly women: a sistematic review
}

\author{
Efeito do treinamento dos músculos do assoalho pélvico na \\ incontinência urinária de mulheres idosas: revisão sistemática
}

\author{
Raquel Henriques Jácomo ${ }^{[\mathrm{a}]}$, Fátima Fani Fitz ${ }^{[\mathrm{b}]}$, Aline Teixeira Alves ${ }^{[\mathrm{c}]}$, Isabella Silveira Fernandes ${ }^{[\mathrm{d}]}$, \\ Fellipe Amatuzzi Teixeira ${ }^{[\mathrm{e}]}$, João Batista de Sousa ${ }^{[\mathrm{f}]}$ \\ [a] MSc student, Universidade de Brasília, Brasília, DF - Brazil, e-mail: raquel.jacomo@gmail.com \\ [b] PhD student, Universidade Federal de São Paulo, Departamento de Ginecologia, São Paulo, SP - Brazil, e-mail: \\ fanifitz@yahoo.com.br \\ [c] PhD student, professor at Universidade de Brasília, Brasília, DF - Brazil, e-mail: alinealves@unb.br \\ [d] Spec., Faculdade de Ciências Médicas de Minas Gerais, Belo Horizonte, MG - Brazil, e-mail: isabellafisioterapia@gmail.com \\ [e] PhD, professor at Universidade de Brasília, Brasília, DF - Brazil, e-mail: famatuzzi@gmail.com \\ [f] PhD, professor at Universidade de Brasília, Brasília, DF - Brazil, e-mail: sousajb@unb.br
}

\begin{abstract}
Introduction: The International Continence Society (ICS) determines that the pelvic floor muscles training (PFMT) is the first-choice treatment of urinary symptoms in women. Objective: The aim of this study was to systematize randomized controlled clinical trials that address the effects of PFMT in the treatment of urinary symptoms in older women using objective outcome measures. Method: Systematic review search was performed eletronic the following databases: Medline, Pubmed, Lilacs, PEDro and manual research conducted in the references of the studies. Were considered eligible women aged over 60 years who performed PFMT in isolation, without the involvement of another technique. The PFMT performed in clinic or at home, with or without the supervision of a therapist and with or without the use of biofeedback as an adjunct. Considered as outcome measures urodynamic studies, voiding diary that assesses daytime urinary frequency, nocturnal urinary frequency, urinary incontinence and exchange absorbent, and, finally, the absorbent test that quantifies loss urinary grams. The assessment of methodological quality of the studies was conducted by PEDro scale. Results: Three studies were reviewed in full. Only one trial was rated high
\end{abstract}


methodological quality. There was significant improvement in urinary symptoms after treatment proposed in the three selected studies. Conclusion: Considering the studies available so far are weak the evidence for the use of PFMT in the treatment of urinary symptoms in elderly women.

Keywords: Exercises therapy. Urinary incontinence. Pelvic floor. Aged. Women's health.

\section{Resumo}

Introdução: A Sociedade Internacional de Continência (SIC) determina que o treinamento dos músculos do assoalho pélvico (TMAP) seja considerado como primeira opção de tratamento dos sintomas urinários nas mulheres. Objetivo: $O$ objetivo deste estudo foi sistematizar ensaios clínicos randomizados e controlados que abordam os efeitos do TMAP no tratamento dos sintomas urinários em mulheres idosas utilizando medidas de desfecho objetivas. Método: Revisão sistemática no qual foi feita uma busca eletrônica nas seguintes bases de dados: Medline, Pubmed, Lilacs, PEDro e pesquisa manual realizada nas referências bibliográficas dos estudos. Consideraram-se elegíveis mulheres idosas acima de 60 anos, que realizaram o TMAP de forma isolada, sem envolvimento de outra técnica. O TMAP realizado em ambulatório ou em domicílio, com ou sem a supervisão de um terapeuta e com ou sem o uso do biofeedback como adjuvante. Considerou-se como medidas de desfecho o estudo urodinâmico, o diário miccional que avalia a frequência urinária diurna, a frequência urinária noturna, perda urinária aos esforços e a troca de absorventes, e, por fim, o teste do absorvente que quantifica a perda urinária em gramas. A avaliação da qualidade metodológica dos estudos foi realizada pela escala PEDro. Resultados: Três estudos foram revisados na íntegra. Apenas um artigo foi classificado como de alta qualidade metodológica. Houve melhora significativa dos sintomas miccionais após o tratamento proposto nos três estudos selecionados. Conclusão: Considerando os estudos disponíveis até o momento são fracas as evidências favoráveis à utilização do TMAP no tratamento dos sintomas urinários de mulheres idosas.

Palavras-chave: Exercício. Incontinência urinária. Diafragma da pelve. Idoso. Saúde da mulher.

\section{Introduction}

According to the International Continence Society (ICS), urinary incontinence (UI) is defined as any involuntary loss of urine (1). It is one of the most common problems of public health in elderly women, creating a great impact in the quality of life of the institutionalized population as well as the population that resides in the community $(2,3)$.

It is a non-inherent change in the aging process, but its incidence is increased linearly with age, which can be considered as a geriatric syndrome due to the high prevalence in these individuals. It is estimated that about $39 \%$ of women over 60 years of age show daily urine loss. With this in mind, treatment for urinary incontinences becomes primordial $(3,4,5)$.

An efficient treatment for urinary incontinence requires studying women as a whole, taking in consideration not only the pathology, but also the social and emotional aspects involved. Surgical treatment is usually one of the first-choice treatments that come to mind, however, interest in a more conservative solution has increased. The ICS recommends that the conservative treatment be considered as the first option of intervention in incontinent women (6).

As a first-choice conservative treatment, pelvic floor muscles training (PFMT), as first proposed by Kegel, with the goal to increase support of the inferior urinary tract, as well as promote the urethral closing by involuntary contraction of the periurethral muscles are highly recommended (7). Although the conservative method has shown efficiency in treating adult women $(8,9,10)$, in elderly women the focus is still to manage the consequences $(11,12,13)$, and not in treating the dysfunction.

Within the outcome measures that can be taken into consideration to evaluate the severity of the urinary symptoms, subjective and objective instruments are mentioned. The objective outcome measures show higher scientific relevance, as they are recommended by the ICS (6). With this, the present study systematizes clinical trials that approach the 
PFMT effect when treating urinary symptoms in elderly women that use objective outcome measures as a way to measure the severity of these urinary symptoms before and after PFMT.

\section{Method}

The present study is a systematic review of random and controlled clinical trials. An extensive electronic research was made in the month of November, 2012 to identify the relevant articles. The following database was used: MedLine (July, 1970-December, 2012), Pubmed (July, 1970-November, 2012), Lilacs (January, 2000-November, 2012) and PEDro (July, 1984-November, 2012) as well as manual bibliographical reference research of the studies. According to the Medical Subject Heading of the National Library of Medicine (MeSH), exercise therapy, urinary incontinence, aged and elderly were used as descriptors.

One reviewer showed search results with potentially eligible articles. Two reviewers assessed the pursuit of eligible articles and an independent third reviewer solved possible disagreements that may have arisen when deciding which articles to include.

\section{Selection of the studies}

Only random and controlled clinical trials written in the English language were elected. The criteria used for selecting the articles were studies that treated elderly women with UI using PFMT. To be included in this research we considered studies in which PFMT was utilized in an isolated manner, without the involvement of other technique, studies in which PFMT was performed in an ambulatory or at home, with or without the supervision of a therapist and with or without the use of the biofeedback as an aid.

To analyze the effect of the PFMT within the severity of the urinary symptoms, we took into consideration studies that used as outcome measures the urodynamic study, the urinary diary which evaluates the frequency of daytime urination, nighttime urination frequency, loss of urinary effort, the absorbent exchange and lastly, the absorbent test that quantifies the loss of urine in grams.

We considered short-term results (three months or less after the randomization), medium-term results (between three months to a year after the follow-up) and long-term results (at least one year of follow-up).

Articles of narrative review, editorials and case studies were not included due to the fact that they did not fit the criteria proposed by this research.

Evaluation of the methodological quality of the studies

The methodological quality of the articles was measured through the PEDro scale (values from 0010). Once available, the points in the PEDro data base were used; otherwise, the studies were classified in an independent manner by two evaluators and an independent third reviewer that solved potential disagreements that might have appeared along the way. Methodological quality was not an inclusion criteria of the articles. Studies that scored 06 (six) points or higher were considered of high quality (14).

\section{Results}

Initially, a total of 596 articles were identified. After removing duplicate articles, 69 articles were selected as eligibly possible based on their title names and abstracts (15-83). From these, 65 were excluded after reading the whole article (15-80), 58 because the subjects didn't meet the age requirement that was pre-established in the study, (15-72), 4 because the PFMT was not done in an isolated fashion (73-76), 1 because it presented only subjective evaluations of the urinary symptoms (77) another one for including men and not demonstrating the results separately (78), and the last 2 because they didn't show the control group $(79,80)$. A flowchart showing the details of the selection process is shown in Figure 1.

In the end, only 3 studies were included (81-83) in the critical appreciation stage regarding the effects of pelvic floor muscle training when treating urinary symptoms in elderly women (Table 1 ).

\section{Methodological quality of the studies}

The methodological quality evaluation performed by the PEDro scale showed an average score of 06 (4-8). Table 2 shows in details the methodological 
quality evaluation of the studies. Two studies compared the PFMT with a control group $(81,83)$ and one article compared the TMAP with the intra-vaginal electro stimulation (82).

The eligibility and randomization were done in all 3 (three) trials, however, in only 2 (two) of them it became clear how the randomization was done. In all 3 (three) articles, the subjects, as well as all therapists, were not completely blind. Only in the Sherburn et al. (2011) trial all evaluators that measured at least one key results did it in a blindly fashion.
Characteristics of the population

included in the studies

The ages averaged between 71 and 79 years. Despite this study consider an elder a person over 60 years of age, the 3 (three) articles chosen used the age of 65 , following the criteria of inclusion proposed by the World Health Organization (WHO), which classifies elderly people as individuals with 65 years or more for developed countries and 60 years or more for undeveloped countries (ONU, 1982) (84).

Research: November/2012

PUBMED: 485

LILACS: 12

Medline: 453

PEDro: 212

Others: 2

Total after removing duplicate studies: 596

Potentially eligible studies after reading title and abstract: 69

Excluded studies: 66

Reasons for exclusion:

- In 58 studies the patients didn't meet the age requirement previously established [15-83]

- In 4 studies the TMAP was not used in an isolated manner [73-76]

- 1 study used subjective outcome measure [77]

- 1 study included both men and women [78]

- 2 studies didn't have a control group $[79,80]$

Figure $\mathbf{1}$ - Detailed flowchart demonstrating the selection process of the studies 


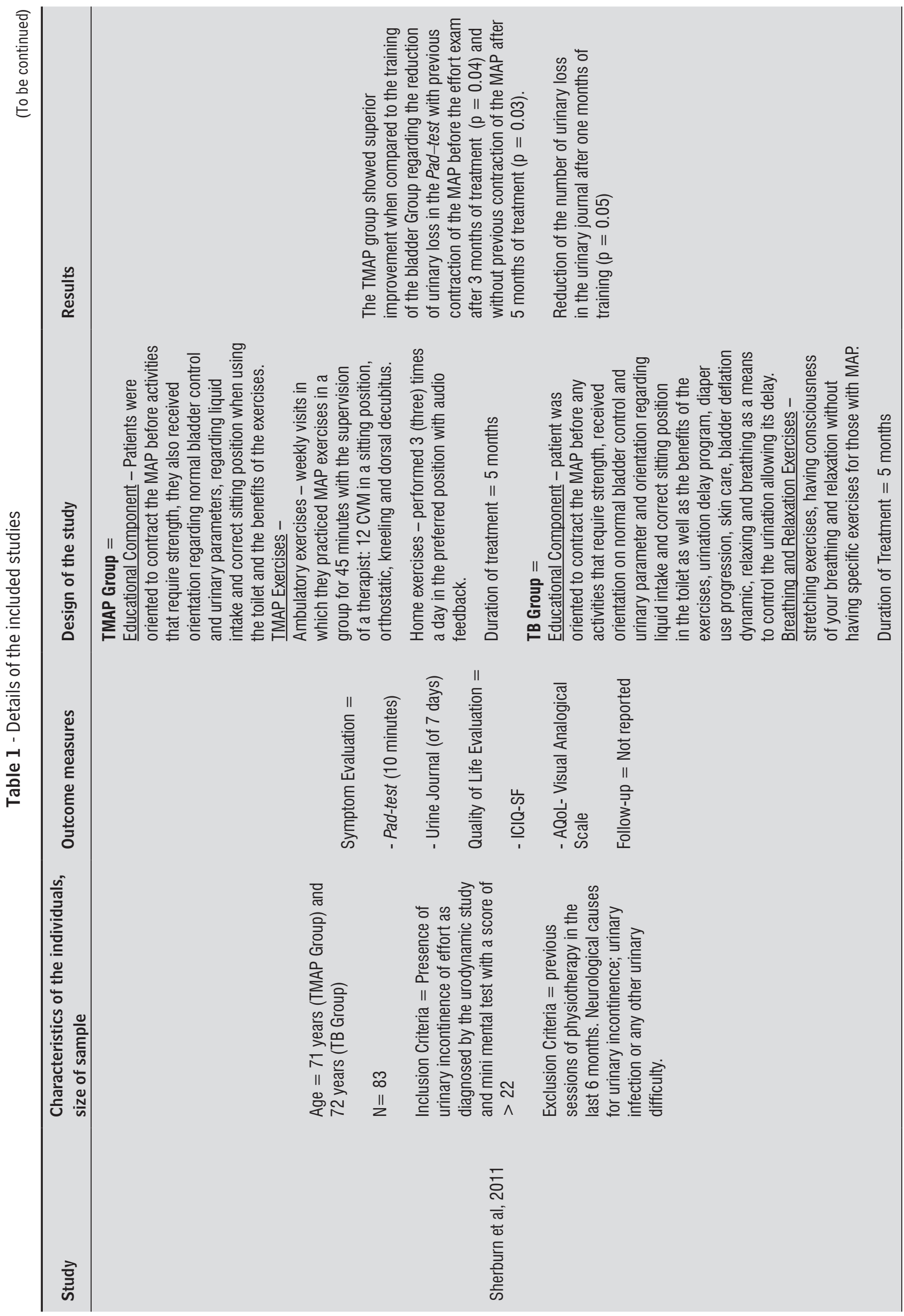




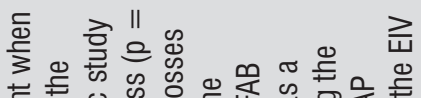

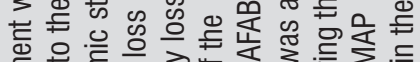

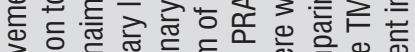

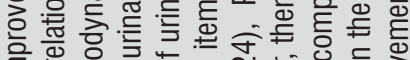

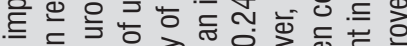
言品

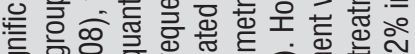

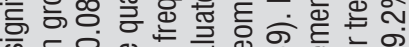

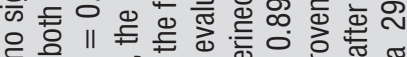

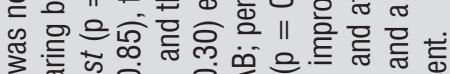

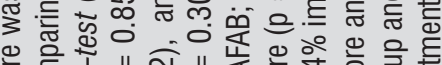

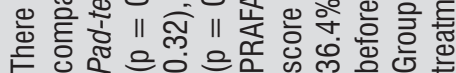

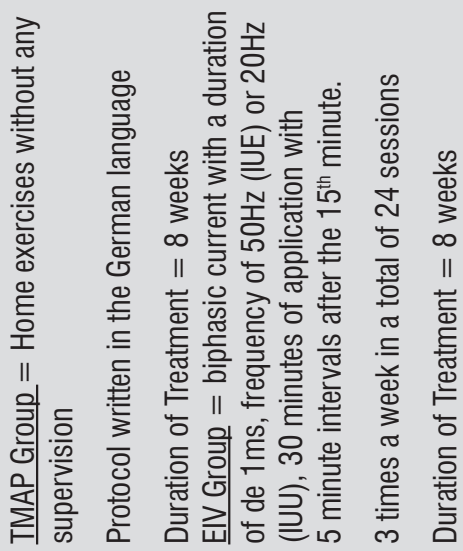

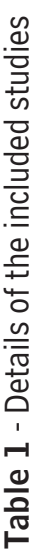

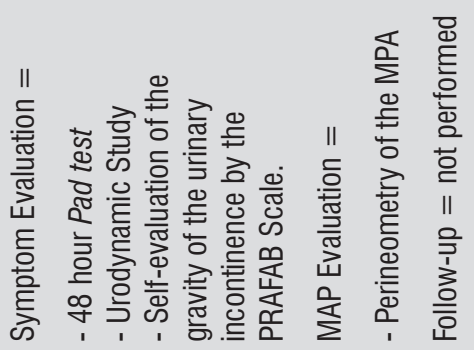

番宁

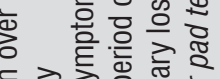

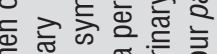

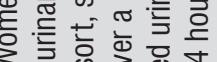
II 言空完产 需 西 is

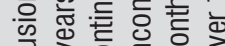
这路

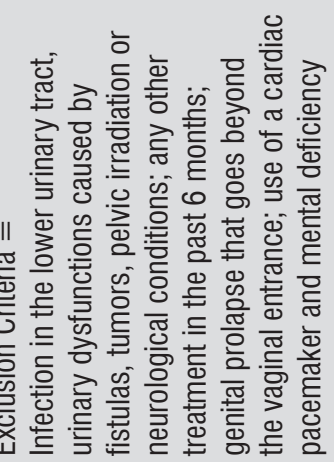

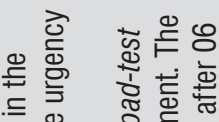

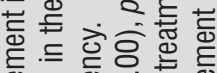

斯

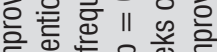

를 을

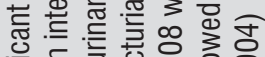

는 도응잉

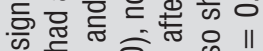

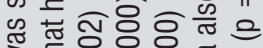

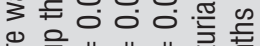

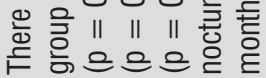

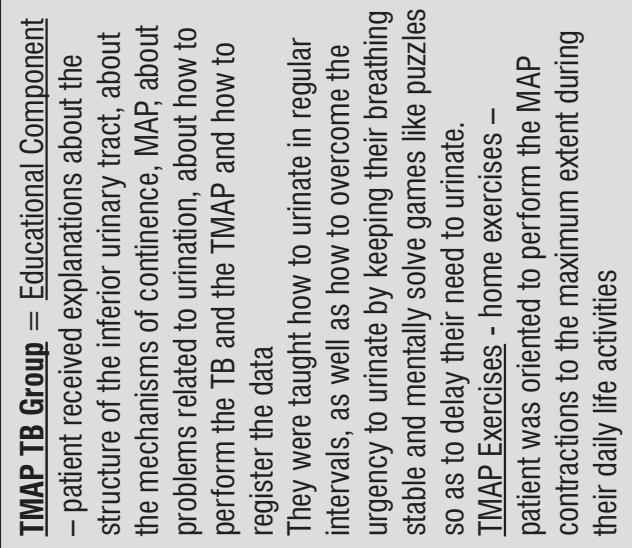

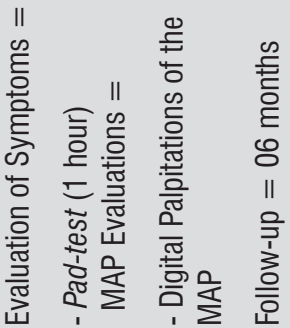

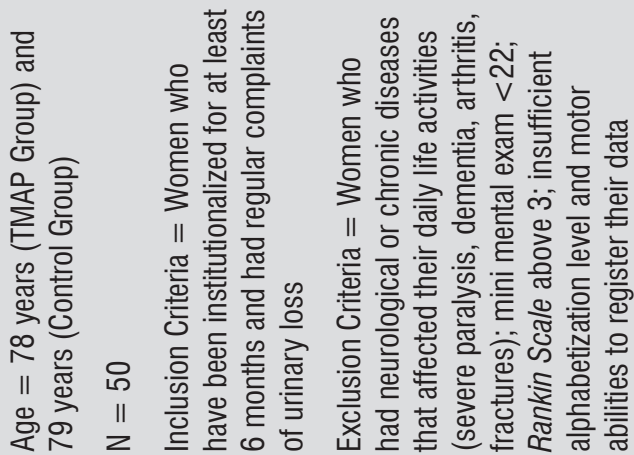

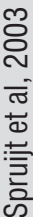

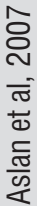




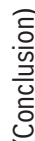

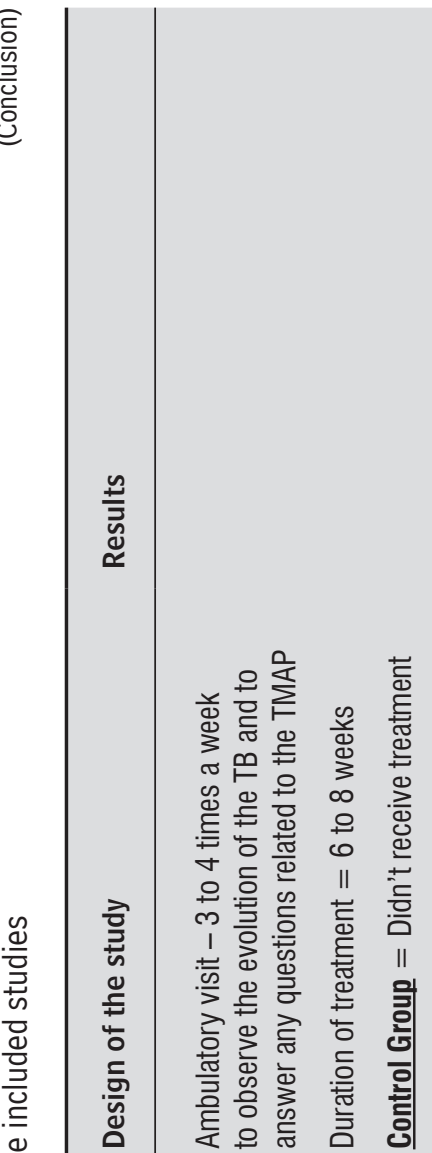

更
흘 흥

S

”基

产

言

노 호

离

至

능 응

II 옹

늠

등

츨 品

ह के

옹

임

뜯

突 응

훈 을

프 등

르 है

कू

氜

흠

需

II II

$\unrhd$ 菂

के

仓 일

ㅎํㅇ

눙

咅

可

पั口

읻 등 동

첸

II

这 总

is

응

을

헝 일

은

잉 잉

II 衤

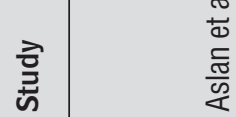

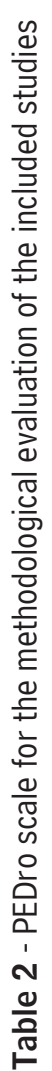

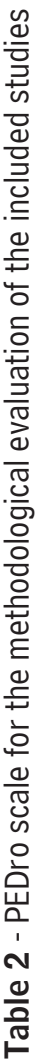

8

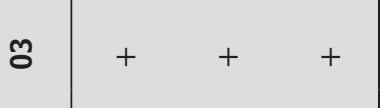

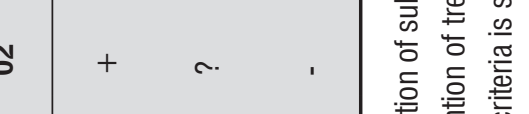

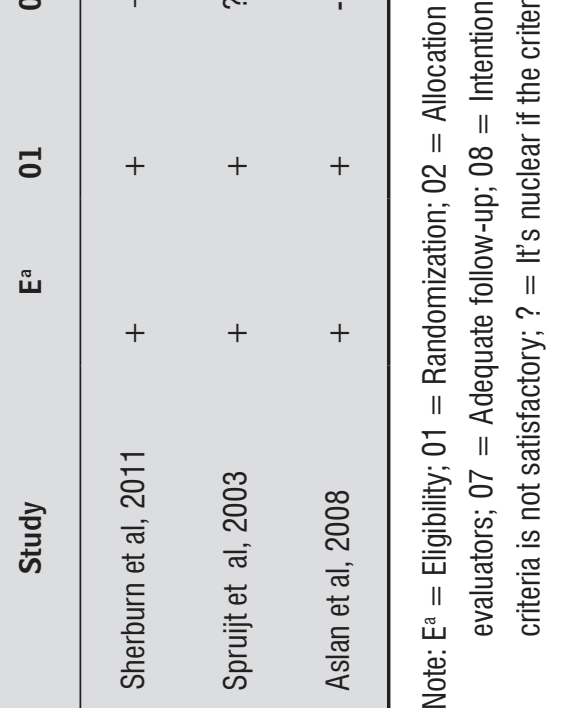


In 2 (two) of the studies, the sample was composed by elderly women that live in a community. Only the Aslan et al study evaluated the training of the pelvic floor muscles in women living in long term institutions. According to the PEDro scale, all studies reached similar results in what concerned more important prognosis indicators.

\section{Training program of the} pelvic floor

The studies turned out to be heterogenic in relation to the TMAP program. The duration of the treatment varied between 6 (six) weeks $(82,83)$ to 5 (five) months (81) and the number of sessions per week was a variable in all 3 (three) studies. Learning to contract the MAP was done by vaginal palpation in 2 (two) of the studies $(82,83$ ) and in another one, the process of learning to contract the MAP was not described. Weekly sessions were held, accompanied by a specialized therapist in TMAP. The execution of the daily home exercises was solicited in all studies $(82,83)$.

Outcome measures used to evaluate urinary symptoms

The objective evaluation of urinary symptoms used in the studies were: the urine journal $(81,83)$, the urodynamic study (82), the related frequency of urinary loss episodes $(81,83)$, and the pad-test $[81$, 83]. The 10 minute pad-test [81], the 1 hour pad-test (83) and the 48-hour pad-test (82) were used.

A significant improvement was observed in the urinary symptoms after the proposed treatment in 2 (two) or 3 (three) selected studies $(81,83)$. Taking in consideration the pad-test as the main source of evaluation, we were able to see a significant improvement in favor of the TMAP in the Sherburn et al. and Aslan et al. trials ( $\mathrm{p}=0.04$ and $\mathrm{p}=0.00$, respectively). There was also a significant improvement in favor of the PFMT group when the urinary journal was analyzed $(81,83)$. Only one study (82) didn't show significant difference in the evaluation of the urodynamic parameters between the group that performed the PFMT and the group that performed the intravaginal electro stimulation.

\section{Discussion}

The literature identified in this review regarding the PFMT in urinary symptoms within elderly women is scarce and the studies are of low methodological quality. Although the efficiency is not proven in this population, preliminary evidence exists that suggest that this type of treatment with the elders is useful and deserves further investigations (85):

The PFMT is a simple method and it is frequently used. The ICS recommends that conservative treatment be the first option of intervention in incontinent women. Meta-Analysis studies prove the effectiveness of PFMT in urinary symptoms of incontinent women (86). However, this therapy hasn't really been used that much in elderly women. The majority of the studies associate PFMT with another technique, which is the primary limitation of this research and, consequently, the reason why most studies have been eliminated (73-75).

Nevertheless, considered as eligible studies were the articles that associated bladder control with PFMT because they all (81-83) provided instructions to the patients on the appropriate liquid intake, normal bladder control and correct urination position. This could be considered a factor of misunderstanding and the result of these studies must be interpreted with caution.

A lot is being written about the effects of bladder training or behavioral therapy in the elderly because this works well according to the cognitive capacity of the patient and it is a common intervention in senior care facilities. It is composed of measures of programmed urination, immediate urination or reeducation of urinary habits. A vast analysis about behavioral training concluded that there is evidence that multiple interventions, including combination of bladder control techniques, PFMT (with or without biofeedback), educational strategies of urination control and self-monitoring are efficient in treating urinary incontinence in independent seniors (87).

Currently there are no guidelines establishing the best treatment protocol for PFMT. None of the chosen studies made use of the biofeedback as a form of PFMT. The current available literature proves that PFMT is efficient in treating women with urinary incontinence $(88,89)$. In this review, 4 (four) articles used biofeedback as a form of TMAP as a treatment for the urinary symptoms in elderly women. However, 
none of them followed the inclusion criteria $(74,77$, 79,80 ).

As for the supervision, only the Sherburn et al. (81) study utilized PFMT in a supervised manner. Spruijt et al. (82)evaluated and provided instructions on how to contract the pelvic floor through vaginal palpitation only on the first meeting. On the other hand, on the Aslan et al. (83) study there were frequent meetings, but no supervised sessions, only an interview at the end of each week to know how the program was evolving. Findings on the supervision of the training are questionable. Felicíssimo et al., comparing the supervised and not supervised PFMT, didn't find any difference between the two groups (90). Zanetti et al., on the other hand, concluded that women that perform the PFMT in a supervised manner show superior results when compared to those that perform without supervision (91). Still, in none of these studies the observed population was composed of elderly women.

Studies that show an agreement between the subjective tools of evaluation are still a conflict $(92,93)$. It has already been proven that the PFMT brings an improvement in the subjective factors as well as the life quality of women with urinary incontinence (94). However, when this question is directed towards the elderly population, no study can be found. Sherburn et al. (81) found an improvement in the evaluated symptoms with the pad test and urinary journal, but when the life quality before and after was evaluated, there was no difference at all. In the Aslan et al. (83) study, it can be observed that in the King Health Questionnaire the results of urinary incontinence didn't affect women on a great scale. It was identified that the general perception of health kept higher scores on both groups.

The method of evaluation varied, being that the only tool of evaluating the present urinary symptoms on all three of them was the Pad-test. Nevertheless, the way it was carried out was different in all three articles. ICS preconizes as an evaluation method of the 24 hour Pad-test (95), however, this form of evaluation can have limiting factors in the female population.

Studies have shown that there is a significant increase in absorbent weight in women when they are in the menopausal transitional phase and women that are in the post-menopausal phase. Women in the post-menopausal phase that don't use hormonal therapy also show significant increase in the absorbent weight, when compared with those that do make use of hormonal replacement therapy.

With this, environmental conditions, usage of hormonal therapy and menopausal states are all factors considered relevant when using the Pad-test as a form of evaluation in this population (96).

Franco et al compared the one-hour Pad-test with subjective outcomes, such as the analogical visual scale, severity of symptoms scale, Stamey grade, in addition to the evaluation of life quality through the surveys: Urogenital Distress Inventory (UDI-6), Incontinence Impact Questionnaire (IIQ-7), and the International Conference on Incontinence Questionnaire (ICIQ-SF). The results showed that only the ICIQ-SF had a correlation with the Padtest (97).

When we analyzed the urinary journal, only 1 (one) article (81) kept the records of over a period of 7 (seven) days. The article written by Aslan et al. (82) only evaluated the daytime and nighttime frequency in question form and presented the results separately, which made it impossible for us to make a deeper comparison. A recently published study evaluated the association of the urinary symptoms with the urinary journal and the cystometric parameters, showing that not only the daytime frequency but the nighttime frequency as well also show significant associations, proving that the urinary journal is a way to evaluate urinary symptoms (98).

It was not possible to keep up with the long term treatment results. Only Aslan et al accompanied the patients over a period of 6 (six) months. In a recent systematic review, it was concluded that PFMT is efficient in treating women with UI on the long run, even without the incentive to continue with the home exercises. However, the study included women of all age groups (99).

Despite methodological diversity between researches, studies show that PFMT seems to be more efficient in treating urinary symptoms in elderly patients. In all articles used, it was possible to identify an improvement in urinary symptoms in the elderly women population. This research corroborates with another review study that was recently published. However, Pereira et al included in their study other types of treatment - the training of the pelvic floor as well as intra-vaginal electro stimulation. They also evaluated the urinary symptoms through subjective methods like questionnaires on life quality and analogical evaluation scale (85). 
The results regarding PFMT are encouraging, however, the fact that there are only 3 (three) articles that actually make use of this therapy in the elderly population limits our conclusions.

\section{Conclusion}

Taking in consideration the available studies up to this moment, the evidence favorable towards the usage of PFMT in treating urinary symptoms in elderly women is weak.

\section{References}

1. Abrams P, Andersson KE, Birder L, Brubaker L, Cardozo L, Chapple C, et al. Fourth International Consultation on Incontinence Recommendations of the International Scientific Committee: evaluation and treatment of urinary incontinence, pelvic organ prolapsed, and fecal incontinence. Neurourol Urodyn. 2010;29(1):213-40.

2. Bogner HR, Gallo JJ, Sammel MD, Ford DE, Armenian HK, Eaton WW. Urinary incontinence and psychological distress in community-dwelling older adults. J AmGeriatr Soc. 2002;50(3):489-95.

3. DuBeau CE, Kuchel GA, Johnson T, Palmer MH, Wagg A. Incontinence in the frail elderly: report from the 4th International Consultation on Incontinence. Neurourol Urodyn. 2010;29(1):165-78.

4. Lifford KL, Townsend MK, Curhan GC, Resnick NM, Grodstein F. The epidemiology of urinary incontinence in older women: incidence, progression, and remission. J Am Geriatr Soc. 2008;56(7):1191-8

5. Buckley BS, Lapitan MCM; Epidemiology Committee of the Fourth International Consultation on Incontinence, Paris, 2008. Prevalence of urinary incontinence in men, women, and children - current evidence: findings of the Fourth International Consultation on Incontinence. Urology. 2010;76(2):265-70.

6. Abrams P, Cardozo L, Fall M, Griffiths D, Rosier P, Ulmsten $\mathrm{U}$, et al. The standardization of terminology of lower urinary tract function: report from the Standardization Sub-Committee of the International Continence Society. Neurourol Urodyn. 2002;21(2):167-78.
7. Kegel AH. Progressive resistance exercise in the functional restoration of the perineal muscles. Am J Obstet Gynecol. 1948;56(2):238-48.

8. Fantl JA, Newman DK, Colling J. Urinary incontinence in adults: Acute and chronic management [Clinical practice guideline No. 2]. Rockville: Department of Health and Services; 1996.

9. Berghmans LC, Hendriks HJ, Bo K, Hay-Smith EJ, De Bie RA, Van W, Van Doorn ES. Conservative treatment of stress urinary incontinence in women: a systematic review of randomized clinical trials. Br J Urol. 1998; 82(2):181-91.

10. Berghmans LC, Hendriks HJ, De Bie RA, van Waalwijk van Doorn ES, Bø K, van Kerrebroeck PE. Conservative treatment of urge urinary incontinence in women: a systematic review of randomized clinical trials. BJU Int. 2000;85(3):254-63.

11. Staats PGM, Tak E, Hopman-Rock M: Aard, omvang en behandeling van ongewild urine verlies in verzorgingshuizen; aanzet tot een protocol. Leiden: TNO Prevention and Health; 1998.

12. Watson CJ, Phillips D, Hands L, Collin J. Claudication distance is poorly estimated and inappropriately measured. Br J Surg. 1997;84(8):1107-9.

13. Watson NM, Brink CA, Zimmer JG, Mayer RD. Use of the Agency for Health Care Policy and Research Urinary Incontinence Guideline in nursing homes. J Am Geriatr Soc. 2003;51(12):1779-86.

14. Maher CG, Sherrington C, Herbert RD, Moseley AM, Elkins M. Reliability of the PEDro scale for rating quality of randomized controlled trials. Phys Ther. 2003; 83(8):713-21.

15. Lo SK, Naidu J, Cao Y. Additive effect of interferential therapy over pelvic poor exercise alone in the treatment of femele urinary stress and urge incontinence: a randomized controlled trial. Hong Kong Physiotherapy Journal. 2003;21(1):37-42

16. Balmforth JR, Mantle J, Bidmead J, Cardozo L. A prospective observational trial of pelvic floor muscle training for female stress urinary incontinence. BJU Int. 2006;98(4):811-7.

17. Schmidt AP, Sanches PR, Silva DP Jr, Ramos JG, Nohama P. A new pelvic muscle trainer for the treatment of urinary incontinence. Int J Gynaecol Obstet. 2009;105(3):218-22. 
18. Wilson PD, Al Samarrai T, Deakin M, Kolbe E, Brown AD. An objective assessment of physiotherapy for female genuine stress incontinence. Br J Obstet Gynaecol. 1987;94(6):575-82.

19. Hung HC, Hsiao SM, Chih SY, Lin HH, Tsauo JY. An alternative intervention for urinary incontinence: retraining diaphragmatic, deep abdominal and pelvic floor muscle coordinated function. Man Ther. 2010; 15(3):273-9.

20. Hahn I, Sommar S, Fall M. A comparative study of pelvic floor training and electrical stimulation for the treatment of genuine female stress urinary incontinence. Neurourol Urodyn. 1991;10(6):545-54.

21. Burns PA, Pranikoff K, Nochajski TH, Hadley EC, Levy KJ, Ory MG. A comparison of effectiveness of biofeedback and pelvic muscle exercise treatment of stress incontinence in older community-dwelling women. J Gerontol. 1993;48(4):M167-74.

22. Yoon HS, Song HH, Ro YJ. A comparison of effectiveness of bladder training and pelvic muscle exercise on female urinary incontinence. Int J Nurs Stud. 2003; 40(1):45-50.

23. Seo JT, Yoon H, Kim YH. A randomized prospective study comparing new vaginal cone and FES-Biofeedback. Yonsei Med J. 2004;31;45(5):879-84.

24. Dattilo J. A long-term study of patient outcomes with pelvic muscle re-education for urinary incontinence. J Wound Ostomy Continence Nurs. 2001; 28(4):199-205.

25. Cammu H, Van Nylen M, Amy JJ. A 10-year follow-up after Kegel pelvic floor muscle exercises for genuine stress incontinence. BJU Int. 2000;85(6):655-8.

26. Ishiko O, Ushiroyama T, Saji F, Mitsuhashi Y, Tamura $\mathrm{T}$, Yamamoto K, et al. beta(2)-adrenergic agonists and pelvic floor exercises for female stress incontinence. Int J Gynaecol Obstet. 2000;71(1):39-44.

27. Wong KS, Fung KY, Fung SM, Fung CW, Tang CH. Biofeedback of pelvic floor muscles in the management of genuine stress incontinence in Chinese women: randomised controlled trial. Physiotherapy. 2001; 87(12):644-8.
28. Borello-France DF, Downey PA, Zyczynski HM, Rause CR. Continence and quality-of-life outcomes 6 months following an intensive pelvic-floor muscle exercise program for female stress urinary incontinence: a randomized trial comparing low- and high-frequency maintenance exercise. Phys Ther. 2008;88(12):1545-53.

29. Lagro-Janssen TL, Debruyne FM, Smits AJ, van Weel C. Controlled trial of pelvic floor exercises in the treatment of urinary stress incontinence in general practice. Br J Gen Pract. 1991;41(352):445-9.

30. Pages IH, Jahr S, Schaufele MK, Conradi E. Comparative analysis of biofeedback and physical therapy for treatment of urinary stress incontinence in women. Am J Phys Med Rehabil. 2001;80(7):494-502.

31. Kaya S, Akbayrak T, Beksaç S. Comparison of different treatment protocols in the treatment of idiopathic detrusor overactivity: a randomized controlled trial. Clin Rehabil. 2011;25(4):327-38.

32. Sugaya K, Owan T, Hatano T, Nishijima S, Miyazato M, Mukouyama H, et al. Device to promote pelvic floor muscle training for stress incontinence. Int J Urol. 2003;10(8):416-22.

33. Berghmans LC, Frederiks CM, de Bie RA, Weil EH, Smeets LW, van Waalwijk van Doorn ES, et al. Efficacy of biofeedback, when included with pelvic floor muscle exercise treatment, for genuine stress incontinence. Neurourol Urodyn. 1996;15(1):37-52.

34. Nygaard IE, Kreder KJ, Lepic MM, Fountain KA, Rhomberg AT. Efficacy of pelvic floor muscle exercises in women with stress, urge, and mixed urinary incontinence. Am J Obstet Gynecol. 1996;174(1 Pt 1):120-5.

35. Theofrastous JP, Wyman JF, Bump RC, McClish DK, Elser DM, Bland DR, et al. Effects of pelvic floor muscle training on strength and predictors of response in the treatment of urinary incontinence. Neurourol Urodyn. 2002;21(5):486-90.

36. Chen HY, Chang WC, Lin WC, Yeh LS, Hsu TY, Tsai HD, et al. Efficacy of pelvic floor rehabilitation for treatment of genuine stress incontinence. J Formos Med Assoc. 1999;98(4):271-6.

37. Berghmans B, van Waalwijk van Doorn E, Nieman F, de Bie R, van den Brandt P, Van Kerrebroeck P. Efficacy of physical therapeutic modalities in women with proven bladder overactivity. Eur Urol. 2002;41(6):581-7. 
38. Sriboonreung T, Wongtra-ngan S, Eungpinichpong W, Laopaiboon M. Effectiveness of pelvic floor muscle training in incontinent women at Maharaj Nakorn Chiang Mai Hospital: a randomized controlled trial. Med Assoc Thai. 2011;94(1):1-7.

39. Kondo A, Yamada Y, Morishige R, Niijima R. An intensive programme for pelvic floor muscle exercises: shortand long-term effects on those with stress urinary incontinence. Hinyokika Kiyo. 1996;42(11):853-9.

40. Mouritsen L, Frimodt-Møller C, Møller M. Long-term effect of pelvic floor exercises on female urinary incontinence. Br J Urol. 1991;68(1):32-7.

41. Moreno AL, Benitez CM, Castro RA, Girão MJ, Baracat EC, de Lima GR. Urodynamic alterations after pelvic floor exercises for treatment of stress urinary incontinence in women. Clin Exp Obstet Gynecol. 2004; 31(3):194-6.

42. Alewijnse D, Metsemakers JF, Mesters IE, van den Borne B. Effectiveness of pelvic floor muscle exercise therapy supplemented with a health education program to promote long-term adherence among women with urinary incontinence. Neurourol Urodyn. 2003;22(4):284-95.

43. Kashanian M, Ali SS, Nazemi M, Bahasadri S. Evaluation of the effect of pelvic floor muscle training (PFMT or Kegel exercise) and assisted pelvic floor muscle training (APFMT) by a resistance device (Kegelmaster device) on the urinary incontinence in women: a randomized trial. Eur J Obstet Gynecol Reprod Biol. 2011;159(1):218-23.

44. Felicíssimo MF, Carneiro MM, Saleme CS, Pinto RZ, da Fonseca AM, da Silva-Filho AL. Intensive supervised versus unsupervised pelvic floor muscle training for the treatment of stress urinary incontinence: a randomized comparative trial. Int Urogynecol J. 2010;21(7):835-40.

45. Zanetti MR, Castro RA, Rotta AL, Santos PD, Sartori M, Girão MJ. Impact of supervised physiotherapeutic pelvic floor exercises for treating female stress urinary incontinence. Sao Paulo Med J. 2007;125(5):265-9.

46. Smith JJ 3rd. Intravaginal stimulation randomized trial. J Urol. 1996;155(1):127-30.
47. Jundt K, Peschers UM, Dimpfl T. Long-term efficacy of pelvic floor re-education with EMG-controlled biofeedback. Eur J Obstet Gynecol Reprod Biol. 2002; 105(2):181-5.

48. Ng SC, Lin TL, Chang SJ, Tai HL, Hu SW, Chen GD. Nursing intervention to enhance efficacy of home practice of pelvic floor muscle exercises in treating mixed urinary incontinence. Int Urogynecol J Pelvic Floor Dysfunct. 2008;19(5):637-42.

49. Henalla SM, Hutchins CJ, Robinson P, MacVicar J. Nonoperative methods in the treatment of female genuine stress incontinence of urine. J Obstet Gynaecol. 1989; 9(3):222-5.

50. Liebergall-Wischnitzer M, Hochner-Celnikier D, Lavy Y, Manor 0, Arbel R, Paltiel O. Paula method of circular muscle exercises for urinary stress incontinence: a clinical trial. Int Urogynecol J Pelvic Floor Dysfunct. 2005;16(5):345-51.

51. Laycock J, Brown J, Cusack C, Green S, Jerwood D, Mann K, et al. Pelvic floor reeducation for stress incontinence: comparing three methods. Br J Community Nurs. 2001;6(5):230-7.

52. Elia G, Bergman A. Pelvic muscle exercises: when do they work? Obstet Gynecol. 1993;81(2):283-6.

53. Huebner M, Riegel K, Hinninghofen $H$, Wallwiener D, Tunn R, Reisenauer C. Pelvic floor muscle training for stress urinary incontinence: a randomized, controlled trial comparing different conservative therapies. Physiother Res Int. 2011;16(3):133-14.

54. Parkkinen A, Karjalainen E, Vartiainen M, Penttinen J. Physiotherapy for female stress urinary incontinence: individual therapy at the outpatient clinic versus home-based pelvic floor training: a 5-year follow-up study. Neurourol Urodyn. 2004;23(7):643-8.

55. Capelini MV, Riccetto CL, Dambros M, Tamanini JT, Herrmann V, Muller V. Pelvic floor exercises with biofeedback for stress urinary incontinence. Int Braz J Urol. 2006;32(4):462-9.

56. Tibaek S, Gard G, Jensen R. Pelvic floor muscle training is effective in women with urinary incontinence after stroke: a randomised, controlled and blinded study. Neurourol Urodyn. 2005;24(4):348-57. Erratum in: Neurourol Urodyn. 2008;27(1):100. 
57. Klarskov P, Belving D, Bischoff N, Dorph S, Gerstenberg T, Okholm B, et al. Pelvic floor exercise versus surgery for female urinary stress incontinence. Urol Int. 1986;41(2):129-32.

58. Arruda RM, Castro RA, Sousa GC, Sartori MGF, Baracat EC, Girao MJBC. Prospective randomized comparison of oxybutynin, functional electrostimulation, and pelvic floor training for treatment of detrusor overactivity in women. Int Urogynecol J Pelvic Floor Dysfunct. 2008;19(8):1055-61.

59. Liebergall-Wischnitzer M, Hochner-Celnikier D, Lavy Y, Manor 0, Shveiky D, Paltiel O. Randomized trial of circular muscle versus pelvic floor training for stress urinary incontinence in women. J Womens Health (Larchmt). 2009;18(3):377-85.

60. Yalcin OT, Hassa H, Ozalp S, Yildirim A, Sener T. Results of the anti-incontinence operations and Kegel exercises in patients with type II anatomic stress incontinence. Acta Obstet Gynecol Scand. 1998;77(3):341-6.

61. Ferguson KL, McKey PL, Bishop KR, Kloen P, Verheul JB, Dougherty M. Stress urinary incontinence: effect of pelvic muscle exercise. Obstet Gynecol. 1990; 75(4): 671-5.

62. Castro RA, Arruda RM, Zanetti MR, Santos PD, Sartori MG, Girão MJ. Single-blind, randomized, controlled trial of pelvic floor muscle training, electrical stimulation, vaginal cones, and no active treatment in the management of stress urinary incontinence. Clinics (Sao Paulo). 2008;63(4):465-72.

63. Kincade JE, Dougherty MC, Busby-Whitehead J, Carlson JR, Nix WB, Kelsey DT, et al. Self-monitoring and pelvic floor muscle exercises to treat urinary incontinence. Urol Nurs. 2005;25(5):353-63.

64. Burgio KL, Robinson JC, Engel BT. The role of biofeedback in Kegel exercise training for stress urinary incontinence. Am J Obstet Gynecol. 1986;154(1):58-64.

65. Hirsch A, Weirauch G, Steimer B, Bihler K, Peschers U, Bergauer $F$, et al. Treatment of female urinary incontinence with EMG-controlled biofeedback home training. Int Urogynecol J Pelvic Floor Dysfunct. 1999; 10(1):7-10.

66. Castleden CM, Duffin HM, Mitchell EP. The effect of physiotherapy on stress incontinence. Age and Ageing. 1984;13(4):235-7.
67. Elser DM, Wyman JF, McClish DK, Robinson D, Fantl JA, Bump RC. The effect of bladder training, pelvic floor muscle training, or combination training on urodynamic parameters in women with urinary incontinence. Continence Program for Women Research Group. Neurourol Urodyn. 1999;18(5):427-36.

68. Kujansuu E. The effect of pelvic floor exercises on urethral function in female stress urinary incontinence: an urodynamic study. Ann Chir Gynaecol. 1983; 72(1):28-32.

69. Henalla SM, Kirwan P, Castleden CM, Hutchins CJ, Breeson AJ. The effect of pelvic floor exercises in the treatment of genuine urinary stress incontinence in women at two hospitals. Br J Obstet Gynaecol. 1988; 95(6):602-6.

70. Aukee $\mathrm{P}$, Immonen $\mathrm{P}$, Laaksonen DE, Laippala $\mathrm{P}$, Penttinen J, Airaksinen 0. The effect of home biofeedback training on stress incontinence. Acta Obstet Gynecol Scand. 2004;83(10):973-7.

71. Schiøtz HA, Karlsen JH, Tanbo TG. Ten-year follow-up after conservative treatment of stress urinary incontinence. Int Urogynecol J Pelvic Floor Dysfunct. 2008; 19(7):911-5.

72. Gameiro MO, Moreira EH, Gameiro FO, Moreno JC, Padovani CR, Amaro JL. Vaginal weight cone versus assisted pelvic floor muscle training in the treatment of female urinary incontinence: a prospective, single-blind, randomized trial. Int Urogynecol J. 2010; 21(4):395-9.

73. Kim H, Suzuki T, Yoshida Y, Yoshida H. Effectiveness of multidimensional exercises for the treatment of stress urinary incontinence in elderly community-dwelling Japanese women: a randomized, controlled, crossover trial. J Am Geriatr Soc. 2007;55(12):1932-9.

74. Simard C, Tu le M. Long-term efficacy of pelvic floor muscle rehabilitation for older women with urinary incontinence. J Obstet Gynaecol Can. 2010;32(12): 1163-6.

75. Kim H, Yoshida H, Suzuki T. The effects of multidimensional exercise on functional decline, urinary incontinence, and fear of falling in communitydwelling elderly women with multiple symptoms of geriatric syndrome: a randomized controlled and 6-month follow-up Trial. Arch Gerontol Geriatr. 2011;52(1):99-105. 
76. Sackley CM, Rodriguez NA, van den Berg M, Badger F, Wright $\mathrm{C}$, Besemer J, et al. A phase II exploratory cluster randomized controlled trial of a group mobility training and staff education intervention to promote urinary continence in UK care homes. Clin Rehabil. 2008;22(8):714-21.

77. Kim J. The development and evaluation of an incontinence intervention program for the elderly women at elderly welfare center. Taehan Kanho Hakhoe Chi. 2004;34(8):1427-33.

78. Engberg S, McDowell BJ, Donovan N, Brodak I, Weber E. Treatment of urinary incontinence in homebound older adults: interface between research and practice. Ostomy Wound Manage. 1997;43(10):18-22, 24-6.

79. Burgio KL, Whitehead WE, Engel BT. Urinary incontinence in the elderly. Bladder-sphincter biofeedback and toileting skills training. Ann Intern Med. 1985;103(4):507-15.

80. Perrin L, Dauphinee SW, Corcos J, Hanley JA, Kuchel GA. Pelvicfloor muscle training with biofeedback and bladder training in elderly women: a feasibility study. J Wound Ostomy Continence Nurs. 2005; 32(3): 186-99.

81. Sherburn M, Bird M, Carey M, Bo K, Galea MP. Incontinence improves in older women after intensive pelvic floor muscle training: an assessor-blinded randomized controlled trial. Neurourol Urodyn. 2011; $30(3): 317-24$.

82. Spruijt J, Vierhout M, Verstraeten R, Janssens J, Burger C. Vaginal electrical stimulation of the pelvic floor: a randomized feasibility study in urinary incontinent elderly women. Acta Obstet Gynecol Scand. 2003; 82(11):1043-8.

83. Aslan E, Komurcu N, Beji NK, Yalcin O. Bladder training and Kegel exercises for women with urinary complaints living in a rest home. Gerontology. 2008;54(4):224-31.

84. Organização das Nações Unidas - ONU. Assembléia Mundial sobre envelhecimento: resolução 39/125. Viena, 1982.

85. Pereira VS, Escobar AC, Driusso P. Effects of physical therapy in older women with urinary incontinence: a systematic review Rev Bras Fisioter. 2012; 16(6):463-8.
86. Dumoulin C, Hay-Smith J. Pelvic floor muscle training versus no treatment, or inactive control treatments, for urinary incontinence in women. Cochrane Database Syst Rev. 2010;(10):CD005654.

87. Behavioural interventions for urinary incontinence in community-dwelling senior: an evidence-based analysis. Health Quality Ontario. Ont Health Technol Assess Ser. 2008;8(3):1-52.

88. Hirakawa T, Suzuki S, Kato K, Gotoh M, Yoshikawa Y. Randomized controlled trial of pelvic floor muscle training with or without biofeedback for urinary incontinence. Int Urogynecol J. 2013;24(8):1347-54.

89. Fitz FF, Resende AP, Stupp L, Sartori MG, Girao MJ, Castro RA. Biofeedback for the treatment of female pelvic floor muscle dysfunction: a systematic review and meta-analysis. Int Urogynecol J. 2012; 23(11):1495-516

90. Felicíssimo MF, Carneiro MM, Saleme CS, Pinto RZ, da Fonseca AM, da Silva-Filho AL. Intensive supervised versus unsupervised pelvic floor muscle training for the treatment of stress urinary incontinence: a randomized comparative trial. Int Urogynecol J. 2010;21(7):835-40.

91. Zanetti MR, Castro RA, Rotta AL, Santos PD, Sartori M, Girao MJ. Impact of supervised physiotherapeutic pelvic floor exercises for treating female stress urinary incontinence. Sao Paulo Med J. 2007;125(5):265-9.

92. Liebergall-Wischnitzer M, Paltiel O, Hochner-Celnikier D, Lavy Y, Shveiky D, Manor O. Concordance between one-hour pad test and subjective assessment of stress incontinence. Urology. 2010;76(6):1364-8.

93. Abdel-Fattah M, Ramsay I, Barrington JW. A simple visual analogue scale to assess the quality of life in women with urinary incontinence. J Obst Gynecol Reprod Biol. 2007;133(1):86-9.

94. Fan HL, Chan SS, Law TS, Cheung RY, Chung TK. Pelvic floor muscle training improves quality of life of women with urinary incontinence: a prospective study. Aust N Z J Obstet Gynaecol. 2013;53(3):298-304. doi: 10.1111/ajo.12075.

95. Abrams P, Cardozo L, Fall M, Griffiths D, Rosier P, Ulmsten $U$, et al. The standardisation of terminology in lower urinary tract function: report from the standardisation sub-committee of the International Continence Society. Urology. 2003;61(1):37-49. 
96. Figueiredo EM, Gontijo R, Vaz CT, Baracho E, da Fonseca AM, Monteiro MV, Filho AL. The results of a 24-h pad test in Brazilian Women. Int Urogynecol J. 2012; 23(6):785-9.

97. Franco AM, Lee F, Fynes MM. Is there an alternative to pad tests? Correlation of subjective variables of severity of urinary loss to the 1 -h pad test in women with stress urinary incontinence. BJU Int. 2008; 102(5):586-90.

98. Daan NM, Schweitzer KJ, van der Vaart CH. Associations between subjective overactive bladder symptoms and objective parameters on bladder diary and filling cystometry Int Urogynecol J. 2012;23(11):1619-24.
99. Bo K, Hilde G. Does it work in the long term? A systematic review on pelvic floor muscle training for female stress urinary incontinence. Neurol Urodynamics. 2013;32(3):215-23.

Received: 10/23/2013

Recebido: 23/10/2013

Approved: 04/09/2014

Aprovado: 09/04/2014 